\title{
Drying and Osmotic Conditioning in Hancornia speciosa Gomes Seeds
}

\author{
Tathiana Elisa Masetto ${ }^{1}$, Silvana de Paula Quintão Scalon ${ }^{2}$ \\ ${ }^{1}$ Departamento de Ciências Agrárias, Universidade Tecnológica Federal do Paraná - UTFPR, Pato Branco/PR, Brasil \\ ${ }^{2}$ Faculdade de Ciências Agrárias, Universidade Federal da Grande Dourados - UFGD, Dourados/MS, Brasil
}

\begin{abstract}
Hancornia speciosa is a native tree species of the Brazilian Cerrado whose seeds are desiccation sensitive. In this study, we aimed to evaluate drying and osmotic conditioning in H. speciosa seeds. We used fresh seeds with $48 \%$ moisture content, which were slowly dried until they attained contents of $20 \%, 15 \%, 10 \%$ and $5 \%$. To evaluate osmotic conditioning, the seeds were imbibed in $12 \mathrm{~mL}$ osmotic solutions at $0.0 ;-0.2 ;-0.4$ and $-0.6 \mathrm{MPa}$ for two days. After that, they were dehydrated until their original moisture content. The experiments were carried out in a completely randomized design with four repetitions with 50 seeds each. Reduction in moisture content from $20 \%$ to $5 \%$ decreased the physiological potential of seeds. H. speciosa seeds do not require osmotic priming with PEG solutions, because imbibition of seeds in osmotic solutions of up to -0.6 MPa results in reduction of germination rate and seedling length.
\end{abstract}

Keywords: cerrado, polyethylene glycol, seed moisture content.

\section{Secagem e Condicionamento Osmótico em Sementes de Hancornia speciosa Gomes}

\section{RESUMO}

A Hancornia speciosa é uma espécie arbórea nativa do Cerrado brasileiro, cujas sementes são sensíveis à dessecação. Objetivou-se no presente trabalho avaliar a secagem e o condicionamento osmótico em sementes de H. speciosa. Foram utilizadas sementes com $48 \%$ de teor de água, que foram secas lentamente até atingirem $20 \%, 15 \%, 10 \%$ e $5 \%$ de teor de água. Para avaliar o condicionamento osmótico, as sementes foram embebidas em $12 \mathrm{~mL}$ de soluções de polietilenoglicol nos potenciais osmóticos de 0,$0 ;-0,2 ;-0,4$ e - $0,6 \mathrm{MPa}$ durante dois dias. Em seguida, as sementes foram secas até o teor de água original. Os experimentos foram conduzidos em delineamento inteiramente casualizado com quatro repetições de 50 sementes. A redução do teor de água de $20 \%$ até $5 \%$ reduziu o potencial fisiológico das sementes. As sementes de $H$. speciosa não necessitam de condicionamento osmótico, uma vez que a embebição das sementes nas soluções osmóticas de até -0,6 MPa resulta na redução da porcentagem de germinação e do comprimento de plântulas.

Palavras-chave: cerrado, polietilenoglicol, teor de água de sementes. 


\section{INTRODUCTION}

There is growing concern about the need to conserve the earth's natural resources, especially because the biodiversity of rainforest plants is in danger owing to uncontrolled exploitation. The extinction potential of a species is related to the degree of its biological vulnerability and the degree of threat by biotic and abiotic factors; therefore, ex-situ conservation is an important strategy for the preservation of tropical species (Phartyal et al., 2002).

One of the most important $e x$-situ strategies for key groups of species is seed banking, which is often used because of the following characteristics: seeds are relatively easy to collect, can represent a range of genetic diversity in the species if harvested from a population of individuals, and can be stored in a relatively small space (Li \& Pritchard, 2009).

Given the appropriate facilities, storage for all these purposes can be readily achieved, but only if seeds exhibit orthodox post-harvest physiology (Roberts, 1973). Recalcitrant seeds, in contrast, are characterized by post-harvest life spans of the order of days to months or, for temperate species, perhaps a year or two, as long as such seeds tolerate low (not sub-zero) temperatures. Besides producing shortlived seeds, many of the recalcitrant seed species are threatened by overexploitation, indiscriminate harvesting, and habitat loss (Berjak, 2005). Hancornia speciosa is a typical native fruit species from Brazil and occurs naturally in the Southwest, Northwest and West-Central regions of Brazil. Besides the in natura consumption of $H$. speciosa fruits, they can be used in juices, ice cream and jelly (Souza et al., 2007). However, according to Barros et al. (2006), its population is reducing due to the agricultural exploitation and deforestation. Moreover, H. speciosa is still under domestication and requires major care because its seeds are desiccation sensitive, and the employment of ex-situ; i.e., seed banks, for the species conservation might be threatening.

Thus, some techniques usually applied to improve the seed propagation of this species, such as osmotic conditioning, may possibly be efficient in increasing the germination rate of $H$. speciosa seeds. Osmotic priming has been used to promote rapid and uniform germination. This technique is based on the controlled hydration of seeds to a level that allows pre-germinative metabolic activity, but inhibits radicular emergence; this is achieved by immersing the seeds in an aqueous solution of a chemically inert but osmotically active compound. The osmotic potential is adjusted to allow all the pre-germination processes, while impeding cellular prolongation and, hence, radicular emergence, even after weeks of contact between the seeds and the osmotic solution (Khan, 1992). During osmotic priming, the seed is slowly moisturized allowing more time for repair or reorganization of plasma membranes, which results in more orderly tissue formation and reduces the risk of damage to the embryonic axis caused by the fastsoak method. Several physiological changes occur in seeds during, or as a consequence of osmotic priming, including the breaking of dormancy and increased germinative power and vigor (Khan, 1992).

Despite the species importance to the Brazilian native fruit growing, major efforts are still needed to understand the minimum moisture content at which seeds can withstand desiccation and resume seedling growth. In addition, it has been suggested that osmotic priming might improve the production of high-quality seedlings. Therefore, the objective of this study was to evaluate the effect of dehydration at low moisture contents in $H$. speciosa seeds and the relationship between osmotic priming solutions and seed physiological performance.

\section{MATERIAL AND METHODS}

The experiment was carried out at the Seed Laboratory, Department of Agrarian Sciences of the Federal University of Grande Dourados, in the municipality of Dourados, Mato Grosso do Sul state, Brazil.

\subsection{Plant material}

Ripe fruits of $H$. speciosa were collected from twelve trees in the municipality of Dourados, Mato Grosso state, Brazil (S $23^{\circ} 02^{\prime} 37^{\prime \prime}$ and W $55^{\circ} 09^{\prime} 10^{\prime \prime}$ ) in the native Cerrado stricto sensu area. The climate in 
this region is classified as "Cwa" according to Köppen, with average temperature and rainfall ranging from 20 to $24^{\circ} \mathrm{C}$ and 1250 to $1500 \mathrm{~mm}$, respectively. After collection, the fruits were processed immediately by maceration on a sieve under running water so that seeds were separated from fruit residues. The seeds were then spread on paper towel over the lab bench where they were allowed to rest for five minutes to remove the superficial water.

\subsection{Seed moisture content and germination}

Initially, seed moisture content was determined. It was assessed in four replications of $2 \mathrm{~g}$ each (approximately 8 seeds) through oven-drying at $105 \pm 2{ }^{\circ} \mathrm{C}$ for 24 hours (Brasil, 2009) and expressed as percentage moisture content on a fresh weight basis. The germination tests were performed in four replications of 50 seeds each, on sand inside plastic germination boxes, in a biological oxygen demand (B.O.D.) chamber at $25{ }^{\circ} \mathrm{C}$ under continuous white light for 60 days.

\subsection{Seed dehydration}

In order to assess seed dehydration, characterization of seed desiccation tolerance was conducted according to Hong \& Ellis (1996), following the slow seed dehydration. Seeds were then kept in a thin layer under laboratory conditions $\left(25 \pm 2{ }^{\circ} \mathrm{C} / 60 \pm 4 \% \mathrm{RH}\right.$, using air-conditioning) where they were weighed at intervals to detect the target weights corresponding to the target moisture content, according to Sacandé et al. (2005). At approximately every five percentage points $( \pm 2)$ of decrease in moisture content $(20 \%, 15 \%, 10 \%$ and $5 \% \pm 2$, which required 24,72 and 108 hours of dehydration, respectively), the seeds were sampled for germination test and moisture content determination. After dehydration, the seeds were pre-humidified in a humid chamber (100\% RH) for $24 \mathrm{~h}$ at $25^{\circ} \mathrm{C}$ in the dark and then rehydrated under the same conditions used for germination.

The effect of seed desiccation was evaluated according to the following characteristics: Germination rate - seeds were examined daily to evidence visible germination; germination was defined as visible radicle protrusion through the pericarp and was noted as the time of first radicle protrusion and $50 \%$ radicle protrusion of the germinated seeds; seedling growth - the aerial part and root length of the seedlings were examined based on ten seedlings, which were measured using a millimeter ruler and the results were expressed as $\mathrm{cm}$ seedling ${ }^{-1}$; fresh mass was evaluated in the same seedlings using a balance and the results were expressed as g seedling $^{-1}$.

\subsection{Seed priming}

In order to evaluate the effect of osmotic conditioning, fresh seeds of $H$. speciosa were osmotically primed by immersion, for two days, in aerated liquid polyethylene glycol 6000 PEG solutions adjusted to the following osmotic potentials: $0.0 ;-0.2 ;-0.4$ and $-0.6 \mathrm{MPa}$. The priming was carried out in a biological oxygen demand (B.O.D.) chamber at $25{ }^{\circ} \mathrm{C}$ in the presence of light. After the priming period, the samples of the primed seeds were removed, washed in water, and then spread on paper towel for five minutes to remove the superficial water. After that, the moisture content of the primed seeds was determined and seeds were submitted to dehydration to attain the original seed moisture content.

The seeds were sowed as previously described and were then evaluated according to the following characteristics: Germination rate - germination was defined as the visible radicle protrusion through the pericarp and was noted as the time of first radicle protrusion and $50 \%$ radicle protrusion of the germinated seeds; seedling root length - they were examined based on ten seedlings, which were measured using a millimeter ruler and the results were expressed as $\mathrm{cm}$ seedling ${ }^{-1}$.

\subsection{Experimental design and statistical analysis}

The experiments were conducted using a completely randomized design with four replications for each treatment, with 50 seeds each. Each experiment was repeated at least two times. Analysis of variance (ANOVA) of data was performed by means of SANEST software. 


\section{RESULTS AND DISCUSSION}

\subsection{Seed dehydration}

The freshly harvested seeds of $H$. speciosa showed $48 \%$ moisture content and 38\% germination. These results are lower than those found by Nogueira et al. (2003), who observed $68 \%$ germination in seeds harvested in Sirinhaém, Pernanbuco state, but the authors did not mention the moisture content of seeds. Barros et al. (2006) observed 50.3\% moisture content and over $80 \%$ germination in seeds harvested in João Pessoa, Paraiba state.

Significant differences were found in seed moisture content (MC) only regarding fresh mass (Figure 1D). Although regression adjustment was not observed for seed germination, there was no remarkable increase in seed germination at 10\% MC dehydration (Figure 1A). The same behavior was noted for the aerial part and root length of seedlings, although no regression adjustment was observed (Figures 1B and 1C, respectively). In addition, it was possible to observe that seed dehydration at $20 \%$, $15 \%$ and 5\% MC showed similar behavior, unlike seedling fresh mass, which presented higher results for seeds at 15\% MC dehydration and also higher regression adjustment (Figure 1D).

Although no decrease in the vigor of H. speciosa seeds was observed, the decrease in desiccation might be associated with the initial moisture content of seeds. Santos et al. (2010) observed that fresh seeds of $H$. speciosa showed $56 \%$ moisture content, and after 72 hours of dehydration they attained 31\% moisture content, corresponding to approximately $73 \%$ emergence. No harm to seedling root length was reported as result of seed moisture content decrease. The authors explained that the seedlings emerged from seeds dehydrated until 43\% were not harmed. However, seed moisture content below $38 \%$ (48 hours dehydration) induced viability loss of seeds. The authors presumed that such tissue damages caused by dehydration could explain the reduction in seedling emergence.

Probably, the lower seed moisture content observed in the present research occurred because of the advanced maturation process of the fruits harvested, which could reduce seed moisture content and result in low germination rate. Thus, it is possible
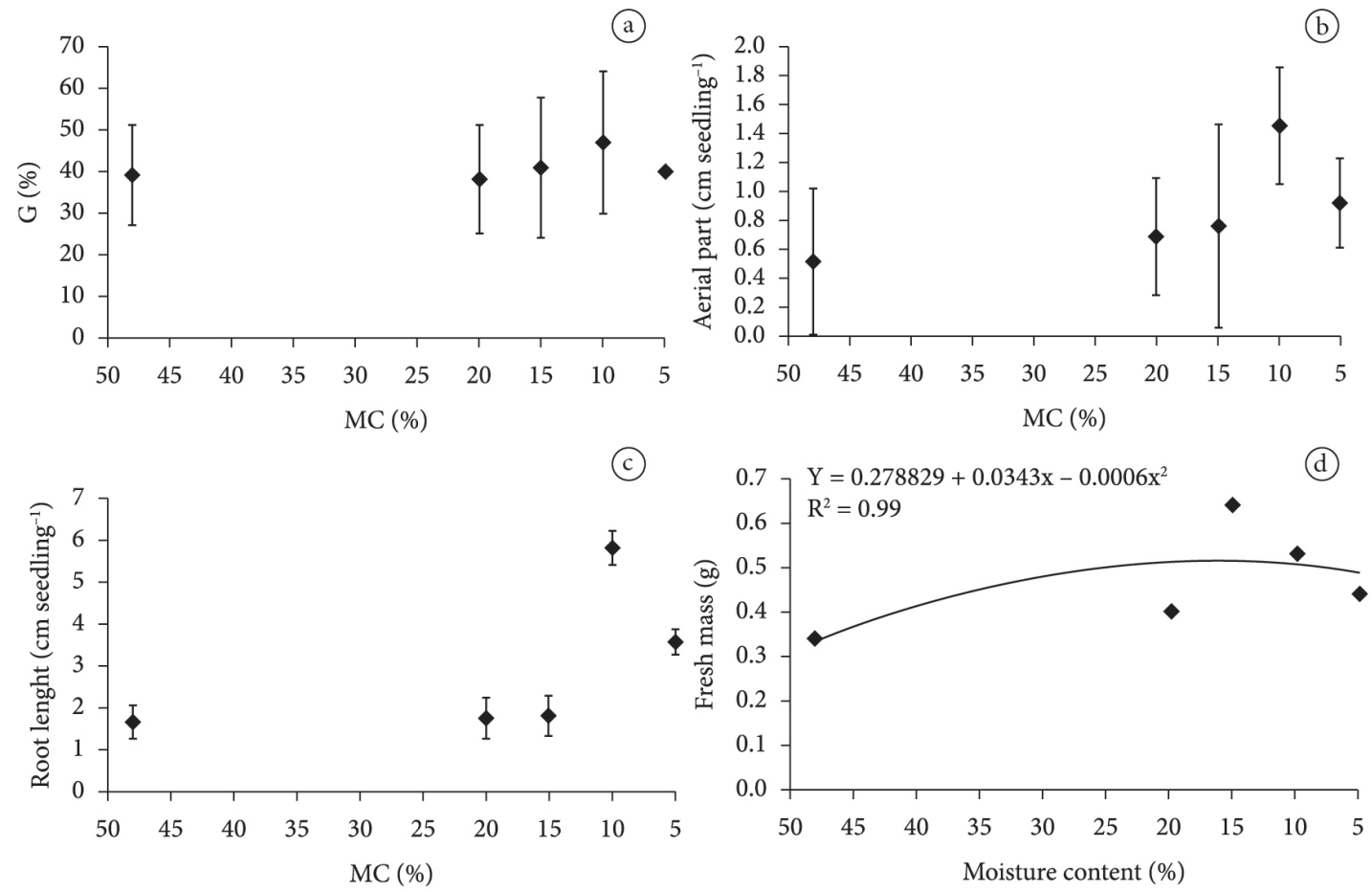

Figure 1. A - Germination rate (G\%); B - aerial part length $\left(\mathrm{cm}\right.$ seedling $\left.{ }^{-1}\right) ; \mathrm{C}$ - root length $\left(\mathrm{cm} \mathrm{seedling}^{-1}\right)$, and $\mathrm{D}$ - fresh mass ( $\mathrm{g}$ seedling ${ }^{-1}$ ) from Hancornia speciosa seeds submitted to different moisture contents after drying. 
that $H$. speciosa seeds could withstand desiccation, and a decrease in MC occurred even when the seeds were inside the fruits, leading to seed viability loss, which was subsequently observed in seed vigor.

There is a wide range of uncertain information about the occurrence of desiccation sensitivity in H. speciosa seeds (Salomão et al., 2004; Barros et al., 2006; Santos et al., 2010) and researches aim to determine the minimum moisture content needed to provide high seed germination rate. However, the conclusions still need more deeply examined to understand the behavior of $H$. speciosa seeds during dehydration; nevertheless, the original results found for seed MC are divergent. Walters (2003) suggested that, for collections of wild plant species, due to the genetic heterogeneity of wild plant populations, any significant decline in viability will result in loss of genotypes from emergence.

\subsection{Seed priming}

Seed moisture contents rose to plateau levels soon after imbibition, and decreased as osmotic potentials decreased (Table 1). Regarding incubation duration, seeds can be considered to be at constant moisture content, in equilibrium with the osmotic potentials set by the external solution.

Table 1. Moisture content (\%) of Hancornia speciosa seeds after priming with PEG (6000) solutions.

\begin{tabular}{|cc|}
\hline PEG (MPa) & Moisture content (\%) \\
\hline 0.0 & 56.6 \\
-0.2 & 51.4 \\
-0.4 & 50.5 \\
-0.6 & 51.5 \\
\hline
\end{tabular}

Seed priming (soaking in water and then drying to storage moisture until use) has been shown to improve crop establishment and, in some instances, to increase crop yields (Ajouri et al., 2004). For instance, a decrease in the germination rate (Figure 2A) and seedling root length (Figure 2B) of $H$. speciosa was observed. The experiments reported herein confirm the particular sensitivity of $H$. speciosa seeds after PEG osmotic incubation. In spite of the low initial germination rate of $H$. speciosa seeds, osmotic priming did not improve the physiological potential of seeds; on the contrary, results of the PEG treatment showed a reduction in initial seedling growth. This is consistent with the drastic reduction in the total germination rates and root length observed at the osmotic potentials of up $-0.6 \mathrm{MPa}$. This is in agreement with previous studies, which have also found that increasing priming might reduce the vigor characteristics of some tree species, as observed in non-primed seeds of Australian royal palm (Archontophoenix alexandrae), which showed a higher germination rate index than those primed with PEG (Teixeira et al., 2007). Water conditioning of red oak (Quercus $s p$ ) after pericarp rupture showed faster seedling establishment and uniformity than osmotic conditioning (Struve, 1998). Osmotic priming with PEG reduced the germination rate and seedling growth characteristics of Stryphnodendron adstringens seeds, but did not alter the physiological potential of S. obovatum and S. polyphyllum seeds (Kissmann et al., 2010), native trees from the Brazilian Cerrado, as $H$. speciosa. Thus, in several species, osmotic priming does not promote seed usefulness. (a)

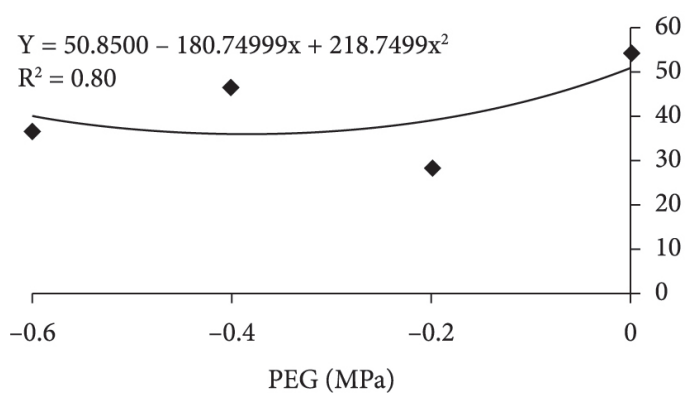

(b)

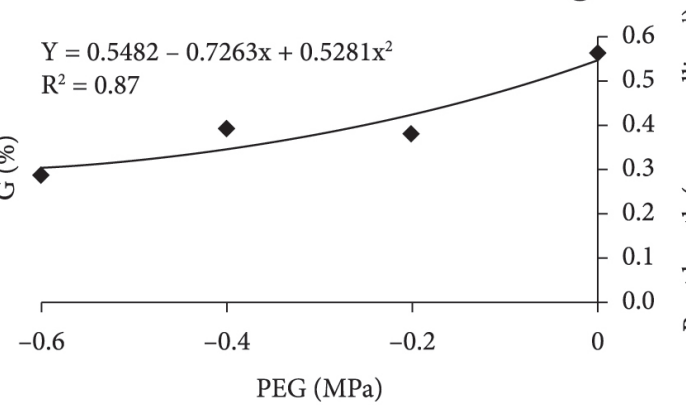

Figure 2. A - Germination rate $(\mathrm{G} \%)$ and B - root length $\left(\mathrm{cm}\right.$ seedling $\left.{ }^{-1}\right)$ of Hancornia speciosa seeds submitted to osmotic priming with different osmotic solutions (PEG 6000). 
However, all the studies have concentrated on improving seed germination after osmotic priming and, to the best of our knowledge, there is no information available on the effects of priming on enhancing seedling performance of $H$. speciosa seeds PEG-treated.

The resulting parameters were used to predict seed germination and initial seedling growth after osmotic priming and drying until H. speciosa seeds initial moisture content. Perhaps, H. speciosa seeds did not withstand drying after osmotic priming, even though moisture content of approximately $45 \%$ was reached. According to the revision of Korkmaz et al. (2004), in seed priming studies, seeds are usually transferred directly from the priming solution to the germination medium, generally resulting in very rapid germination compared with non-primed seeds. Since primed seeds have completed phases I (hydration) and II (lag phase) of germination, they only require a favorable water potential gradient for water uptake in order to begin radicle growth.

Furthermore, the unexpected behavior of $H$. speciosa seeds could occur because of the time of PEG solutions incubation. The environment during priming also influences seed response to priming and Chiu et al. (2002) suggested that different temperatures must be evaluated for each species to determine which one provides the best priming result. The most suitable temperature for the $H$. speciosa seed germination is $25^{\circ} \mathrm{C}$ (data not shown). Therefore, it seems that the factors that govern beneficial changes during priming incubation might not act through a general mechanism involving changes which could lead to the improvement of the physiological potential of $H$. speciosa seeds.

It is a well-established phenomenon that the priming solution significantly improves germination and seedling emergence performance of crop seeds and, therefore, improves stand establishment under field conditions. The reduction observed in $H$. speciosa seeds as a result of osmotic priming could mean a restriction in the range of seed priming for seeds of non-domesticated species. Consequently, further studies should be carried out to certify the effects of osmotic solutions, seed drying, and the events that occur during the PEG incubation on $H$. speciosa seeds.

\section{CONCLUSIONS}

Dehydration of $H$. speciosa seeds below $20 \%$ and up to $5 \%$ do not reduce seed physiological potential. Hancornia speciosa seeds do not require osmotic priming with PEG solutions to attain high seed germination rates.

\section{SUBMISSION STATUS}

Received: 07/26/2013

Accepted: 01/28/2014

Published: 02/31/2014

\section{CORRESPONDENCE TO}

\section{Tathiana Elisa Masetto}

Departamento de Ciências Agrárias, Universidade Tecnológica Federal do Paraná - UTFPR, CEP 85503-390, Pato Branco, PR, Brasil

e-mail: tmasetto@gmail.com

\section{REFERENCES}

Ajouri A, Asgedom H, Becker M. Seed priming enhances germination and seedling growth of barley under conditions of $\mathrm{P}$ and $\mathrm{Zn}$ deficiency. Journal of Plant Nutrition and Soil Science 2004; 167(5): 630-636. http://dx.doi.org/10.1002/jpln.200420425

Barros DI, Bruno RLA, Nunes HV, Cabral GC, Pereira WE, Mendonça RMN. Métodos de extração de sementes de mangaba visando à qualidade fisiológica. Revista Brasileira de Fruticultura 2006; 28(1): 25-27. http://dx.doi.org/10.1590/S0100-29452006000100010

Berjak P. Protector of the seeds: seminal reflections from southern Africa. Science 2005; 307(5706): 47-49. PMid:15637256. http://dx.doi.org/10.1126/ science. 1108429

Brasil. Ministério da Agricultura, Pecuária e Abastecimento. Regras para Análises de sementes. Brasília: SNDA/DNDV/CLAV; 2009. 399 p. [cited 2013 maio 1]. Available from: http://www.agricultura. gov.br/arq_editor/file/3376_regras_para_analise_de_ sementes.pdf.

Chiu KY, Chen CL, Sung JM. Effect of priming temperature on storability of primed sh-2 sweet corn seed. Crop Science 2002; 42: 1996-2003. http://dx.doi. org/10.2135/cropsci2002.1996

Hong TD, Ellis RH. A protocol to determine seed storage behavior. Rome: IPGRI, Department of Agriculture the 
University of Reading, United Kingdom; 1996. (IPGRI Techinical Bulletin n. 1). 62 p.

Khan AA. Preplant physiological seed conditioning. Horticultural Review 1992; 13: 131-181.

Kissmann C, Scalon SPQ, Mota LHS, Vieira MC. Germinação de sementes de Stryphnodendron Mart. osmocondicionadas. Revista Brasileira de Sementes 2010; 32(2): 26-35. http://dx.doi.org/10.1590/S010131222010000200003

Korkmaz A, Tiryaki I, Nuri Nas M, Ozba N. Inclusion of plant growth regulators into priming solution improves low-temperature germination and emergence of watermelon seeds. Canadian Journal of Plant Science 2004; 84(4): 1161-1165. http://dx.doi.org/10.4141/P04028

Li DZ, Pritchard HW. The science and economics of ex situ plant conservation. Trends in Plant Science 2009; 14(11): 614-621. PMid:19818672. http://dx.doi. org/10.1016/j.tplants.2009.09.005

Nogueira RJMC, Albuquerque MB, Silva FJ Jr. Efeito do substrato na emergência, crescimento e comportamento estomático em plântulas de mangabeira. Revista Brasileira de Fruticultura 2003; 25(1): 15-18. http:// dx.doi.org/10.1590/S0100-29452003000100006

Phartyal SS, Thapliyal RC, Koedam N, Godefroid S. Ex situ conservation of rare and valuable forest tree species through seed-gene banks. Current Science 2002; 83(11): 1351-1357.

Roberts EH. Predicting the storage life of seeds. Seed Science and Technology 1973; 1: 449-514.
Sacandé M, Joker D, Dulloo M, Thomsen KA. Comparative storage biology of tropical tree seeds. Roma: International Plant Genetic Resources Institute; 2005.

Salomão NA, Santos IRI, Mundim RC. Conservação, manejo e uso de sementes de Hancornia speciosa Gomez (Apocynaceae). Brasília: Embrapa Recursos Genéticos e Biotecnologia; 2004.

Santos PCG, Alves EU, Guedes RS, Silva KB, Cardoso EA, Lima CR. Qualidade de sementes de Hancornia speciosa Gomes em função do tempo de secagem. Semina: Ciências Agrárias 2010; 31(2): 343-352. http:// dx.doi.org/10.5433/1679-0359.2010v31n2p343

Souza FG, Figueiredo RW, Alves RE, Maia GA, Araújo IA. Qualidade pós-colheita de frutos de diferentes clones de mangabeira (Hancornia speciosa GOMES). Ciência e Agrotecnologia 2007; 31(5): 1449-1454. http:// dx.doi.org/10.1590/S1413-70542007000500027

Struve DK. Seed conditioning of red oak: a recalcitrant North American seed. Scientia Agrícola 1998; 55(Número especial): 67-73.

Teixeira MT, Vieira HD, Teixeira SL, Silva MF. Influence of disinfestation and osmotic conditioning on the germinating behavior of australian royal palm (Archontophoenix alexandrae) seeds. Revista Brasileira de Sementes 2007; 29(1): 155-159. http://dx.doi. org/10.1590/S0101-31222007000100021

Walters C. Optimising seed banking procedures. In: Smith RD, Dickie JB, Linington SH, Pritchard HW, Probert RJ, editors. Seed conservation: Turning Science into Practice. London: Royal Botanic Gardens; 2003. 